Like Close, astronomer John Dvorak hopscotches through eclipses in Mask of the Sun, but this is science history rather than anecdote. The quotes he interweaves reveal the extraordinary pull the events have had on the human imagination. The writer Virginia Woolf, for instance, who had witnessed the 1927 total solar eclipse in the north of England, wrote of it in her essay 'The sun and the fish' the following year: "Show me the eclipse, we say to the eye; let us see that strange spectacle again."

It's a rich chronicle. Dvorak notes, for instance, how in 1684 Increase Mather, the president of Harvard College in Cambridge, Massachusetts, delayed the graduation ceremony by ten days so that faculty members and students could reach Martha's Vineyard off the state's south coast to see a total eclipse. (Mather, a Puritan minister, was less enlightened about the Salem witch trials less than a decade later, refusing to condemn them.) We see how astronomer Edmond Halley predicted the eclipse that crossed England in 1715, and gathered public observations to improve prediction of the 1724 event that traversed the country to Europe. And we are reminded of the part an eclipse played in Albert Einstein's rise to prominence. In his 1916 elaboration of his general theory of relativity, Einstein had predicted a deviation in the positions of stars
"A total solar eclipse is the most stupendous sight in nature."

ing an eclipse; three years later, English astronomer Arthur Eddington successfully measured it.

Along with other recent studies - such as astronomer Tyler Nordgren's fine Sun Moon Earth (Basic, 2016) and Mark Littmann and Fred Espenak's excellent and thorough Totality (Oxford, 2017) - these books should enrich the understanding of anyone interested in eclipses. They provide a worthy shelf-full for those gearing up for the big US event in August. (I will be viewing it - on my 34 th total-solareclipse expedition - near the path's US start in Salem, Oregon.) And I hope they convince many others to view it live. If you're not in the zone of totality, just remember to wake up early enough to dodge the traffic jams.

Jay Pasachoff is Field Memorial

Professor of Astronomy at Williams

College, Williamstown, Massachusetts, and chair of the International

Astronomical Union's Working Group on

Solar Eclipses.

e-mail:eclipse@williams.edu

\title{
MUSEUMS
}

\section{The life and times of a curiosity-monger}

\section{Henry Nicholls revels in a biography of Enlightenment collector and Royal Society president Hans Sloane.}

$\mathrm{W}$ hat do bloodletting, slavery, journal editing and a silver penis protector have in common? The eighteenth-century physician, collector and president of the Royal Society Hans Sloane.

In Collecting the World, historian James Delbourgo charts Sloane's rags-to-riches transformation, from his birth in 1660 into a family of domestic servants in the north of Ireland, to his death in 1753 as one of the most influential figures in England. Sloane became medic to the rich and famous and used his personal wealth to amass the most celebrated cabinet of curiosities of the age.

Despite his celebrity in life, Sloane has managed to slip almost into obscurity: his name lives on mostly in a handful of street and place names, such as London's Sloane Square. And he remains a shadowy figure in Delbourgo's book. There is little about what he looked like, or about his family life - perhaps because his archives are full of letters to, rather than from, him. But Delbourgo sheds magnificent light on Sloane's larger world, providing great insight into the evolution of Britain's early scientific and global ambitions.

At the age of 16, Sloane survived a "violent haemorrhage", a formative experience from which he emerged with intense ambition. Moving from Ulster to London in 1679 to study medicine, he developed a talent for self-advancement. He exploited the closeknit Anglo-Irish diaspora to cultivate a connection with chemist and fellow of the Royal Society Robert Boyle, and was introduced to philosopher John Locke, naturalist John Ray and physician Thomas Sydenham. Within a decade, Sloane had emerged as a prominent London doctor, and in 1687 he travelled to Jamaica as physician to the island's new governor, the Duke of Albemarle.

Sloane's timing couldn't have been better: he arrived as the island and its sugar plantations were beginning to assume a pivotal role in Britain's empire. Delbourgo does not shy away from the savagery of the slavery from which the colonists profited - violence and oppression that don't seem to have worried Sloane. Indeed, Sloane's description of public tortures and
Collecting the World: The Life and Curiosity of Hans Sloane JAMES DELBOURGO Allen Lane: 2017.

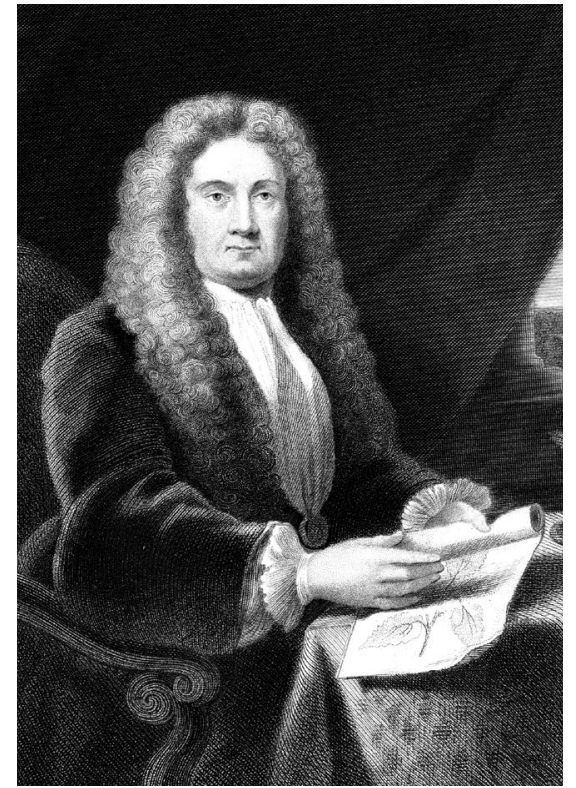

Hans Sloane founded the British Museum.

executions is "eerily dispassionate".

When not attending the duke, plantation owners or their slaves, Sloane indulged his dream of universal knowledge. This resulted in his natural history of the region: a lavish folio published in two volumes (in 1707 and 1725), filled with hundreds of detailed, lifesized engravings of local plants, animals and curios. The work set a new standard for scientific illustration, from which botanists such as Carl Linnaeus would benefit. Sloane distributed copies like calling cards, spreading his work and fame.

There seems no limit to Sloane's curiosity, although he was scathing about witchcraft and magic, and paid special attention to anything that could be transformed into a commodity. Natural history, for him, was "a speculative exercise in scouring the globe for things that might seem odd or trivial ... but which could ultimately triumph in the discovery of prized new resources and goods", writes Delbourgo. Sloane's account of the West Indian manatee (Trichechus manatus) is a perfect example of what Delbourgo calls "total commercial cataloguing". The creatures were "reckon'd extraordinary food"; their cured flesh could last "without corruption ... never turning rancid"; the skeletons, ground to a 
powder, had medicinal properties; and the hides could be transformed into either fine shoes or "whips for beating slaves".

After his return to London in 1689, Sloane married the widow of one of Jamaica's foremost slave owners and bought property in on-the-up Chelsea. In spite of his reliance on treatments such as "superpurgations", he seems to have killed fewer patients than other doctors of his day, bringing him a huge income and the presidency of the Royal College of Physicians in 1719.

As the editor of the Royal Society's journal Philosophical Transactions, he became "one of the pivotal information brokers in the Republic of Letters". Not everything he published was palatable to learned society — including a second-hand report of a 68-year-old woman who had breastfed her grandchildren. Such "vulgar wondermongering", notes Delbourgo, led some to view him as gullible and guilty of distasteful self-promotion: Isaac Newton is said to have described Sloane as "a villain and rascal" and "a very tricking fellow". This didn't stop Sloane from succeeding Newton as president of the Royal Society in 1727 . "With exemplary sociability, redoubtable shrewdness and unflappable patience, he had installed himself at the centre of British society," writes Delbourgo.

As Sloane's star rose, he found it easier to access objects and anecdotes for his personal museum. With immense skill, Delbourgo mines Sloane's vast correspondence to uncover the global networks on which he relied to accumulate miscellanea. The number, variety and curious nature of these objects is enthralling; they include blocks of rock from the Giant's Causeway in Ireland, an arrow-shooter from Indonesia and that silver penis protector, from Panama. Sloane catalogued these and thousands of other books, coins, precious stones, animals and oddities.

In his will, he drew up a guest list for his own funeral, and offered his collection to the nation, presumably as part of his "personal desire for immortality", as Delbourgo puts it. In this mission, he seems to have failed: his name is today rarely linked to the British Museum, the British Library or the Natural History Museum, although all were founded from his collections. "Sloane is nowhere because he was everywhere," suggests Delbourgo.

Sloane's character doesn't lend itself to modern fame: his purging medicine and "hopelessly eclectic" brand of natural history are hard to fathom, and his collections have been buried in later acquisitions. In Collecting the World, Delbourgo brings brilliant resolution to the life and extraordinary times of a fascinating enigma.

Henry Nicholls is a science journalist based in London.

e-mail:henry@henrynicholls.com

\section{Books in brief}

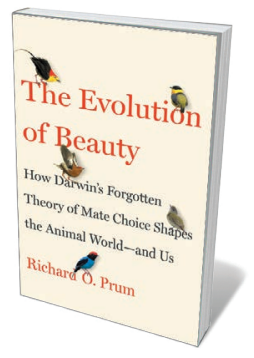

\section{The Evolution of Beauty}

Richard O. Prum DOUBLEDAY (2017)

Charles Darwin called it "the taste for the beautiful". But the theory of sexual selection (reproductive competition pivoting on, say, iridescent plumage) is fiercely debated. In this study, ornithologist Richard Prum seeks to reintegrate it into Darwin's great legacy. Prum, whose research has taken him from Suriname's 'moonwalking' goldenheaded manakin (Ceratopipra erythrocephala) to the "shockingly violent" sex lives of ducks, posits that beauty and desire coevolved, and that because individuals can make maladaptive mating choices, evolution is odder than adaptation can explain.

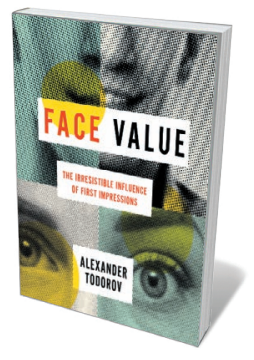

Face Value: The Irresistible Influence of First Impressions

Alexander Todorov PRINCETON UNIVERSITY PRESS (2017)

First impressions and snap judgements are not trivial: they can overturn elections and make or break careers. Drawing on cognitive and computer science, this weighty, well-illustrated study by psychologist Alexander Todorov journeys under the skin to reveal how 'face-reading' - as in the old pseudoscience of physiognomy - has given way to a scientific understanding of perceptual bias vis-à-vis the visage. Todorov unpeels the responses of newborns to "faceness", the hunt for face-selective neurons, the chameleonic self-portraiture of artist Cindy Sherman and more.

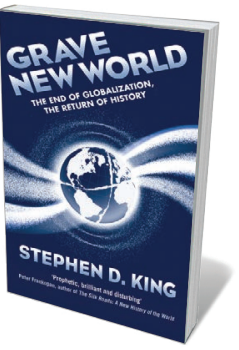

Grave New World: The End of Globalization, the Return of History Stephen D. King YALE UNIVERSITY PRESS (2017)

As cooperative relationships between nation states shift, seven decades of modern globalization could run aground. So argues economist Stephen King in this in-depth survey examining the new world order in light of the old, from the Ottoman Empire to German unification. He analyses the economic impacts of issues such as migration and the teetering reputations of international institutions, looks critically at technocratic trends - and asserts that with China on the rise and an increasingly fragmented geopolitical landscape, "globalization is up for grabs".

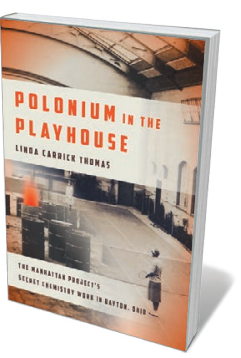

Polonium in the Playhouse

Linda Carrick Thomas TRILLIUM (2017)

How did an indoor tennis court in Dayton, Ohio, become central to the building of the first atomic bomb? Journalist Linda Carrick Thomas chronicles how in the 1940s, chemist Charles Allen Thomas (her grandfather) co-opted the court as a secret poloniumprocessing facility for the Manhattan Project, while choreographing plutonium operations across its many sites. Rich in scientific detail and sidelights, such as the chemist's eye-witness account of the 1945 Trinity test and the story of scientist-spy George Koval, whose Dayton intel enabled the Soviets to build their own bomb postwar.

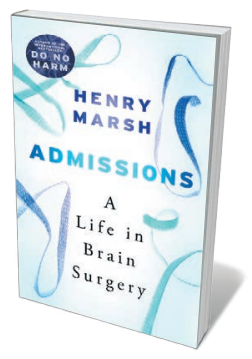

\section{Admissions: A Life in Brain Surgery}

Henry Marsh WEIDENFELD \& NICOLSON (2017)

The horde of physicians now penning memoirs suggests an insatiable demand for expert gut-spilling. And that is no bad thing, given how articulate so many of them are. Henry Marsh, a neurosurgeon for 30 years, is in the front ranks. This thoughtful account (his second, after Do No Harm; W\&N, 2014) charting retirement and surgical work in Nepal and Ukraine brims with insights - not only on the fraught nexus of scalpel and brain, but on the complexities of ageing and the pleasures of beekeeping, tree-planting and carpentry. Barbara Kiser 